\title{
Nivelul seric al proteinei cationice eozinofilice în raport cu eozinofilia şi valoarea oxidul nitric exhalat la copiii cu astm bronşic atopic sensibilizați la aeroalergeni
}

\author{
Ana-Maria Moiceanu Şovărel1,2, Eugenia Buzoianu ${ }^{1,3}$, Mariana Moiceanu ${ }^{3}$, \\ Doina Anca Pleșca ${ }^{1,3}$ \\ ${ }^{1}$ Facultatea de Medicină, Universitatea de Medicină şi Farmacie „Carol Davila“, Bucureşti, România \\ ${ }^{2}$ Spitalul Clinic de Urgenţă „,Sf. Pantelimon“, Bucureşti, România \\ ${ }^{3}$ Spitalul Clinic de Copii „Dr. Victor Gomoiu“, Bucureşti, România
}

\begin{abstract}
REZUMAT
Obiectiv. Evaluarea corelaţiei dintre nivelul seric al proteinei cationice eozinofilice (S-ECP) şi prezenţa eozinofiliei, respectiv nivelul oxidului nitric exhalat (FeNO), la copiii cu astm sensibilizaţi la aeroalergeni.

Material şi metodă. Studiu prospectiv care a inclus 63 copii cu astm bronşic sensibilizaţi la aeroalergeni cu vârsta între 5 şi 18 ani, desfăşurat în Clinica de Pediatrie a Spitalului Clinic de Copii „Dr. Victor Gomoiu“ între aprilie 2016 şi iulie 2017.

Iniţial, s-au determinat nivelul S-ECP, prezenţa eozinofiliei şi valoarea FeNO. Ulterior, s-a evaluat semnificaţia statistică a corelaţiilor dintre S-ECP şi prezenţa eozinofiliei, respectiv valoarea FeNO.

Rezultate. 22 dintre pacienţi au avut o valoare normală a S-ECP; dintre aceştia doar 8 prezentau eozinofilie. 41 dintre pacienţii testaţi au avut o valoare crescută a S-ECP; dintre aceştia 28 prezentau eozinofilie. Aplicând funcţia statistică Pearson Chi-Square Test pentru a evalua semnificaţia corelaţiei dintre valoarea crescută a S-ECP şi prezenţa eozinofiliei, am obţinut valoarea $p=0,0146$ (semnificativă statistic).

15 dintre cei 22 pacienţi cu valoare normală a S-ECP aveau concomitent o valoare normală a FeNO, restul de 7 pacienţi având FeNO crescut. 17 dintre cei 41 pacienţi cu valoare crescută a S-ECP au avut valori normale ale FeNO, restul de 24 înregistrând valori crescute ale FeNO. Funcţia statistică Pearson Chi-Square Test aplicată pentru a evalua corelaţia dintre valoarea S-ECP şi nivelul FeNO a furnizat valoarea $p=0,0432$ (semnificativă statistic).

Concluzii. Nivelul crescut al S-ECP se corelează atât cu prezenţa eozinofiliei, cât şi cu valoarea crescută a FeNO la copiii cu astm sensibilizaţi la aeroalergeni.
\end{abstract}

Cuvinte cheie: astm alergic, proteina cationică eozinofilică, eozinofile, oxid nitric, copil

\section{INTRODUCERE}

Astmul bronşic reprezintă cea mai frecventă boală cronică în rândul populației pediatrice. Afecțiunea se caracterizează printr-o mare heterogenitate în ceea ce priveşte fenotipurile clinice, severitatea obstrucției căilor aeriene, gradul de reversibilitate şi răspunsul la tratament (1).

Etiologia astmului bronşic este extrem de complexă şi presupune interacțiunea dintre mai multe tipuri de factori (8). Dintre aceştia, menționăm factori care țin de individ (factori primari, care sunt în marea lor majoritate genetici) şi factori care țin de mediul înconjurător (8).

Printre factorii individuali se numără factorii genetici (care codifică atopia, hiperreactivitatea bronşică, responsivitatea la tratament, remodelarea bronşică şi evoluția bolii), sexul, activitatea fizică şi obezitatea (8).

De-a lungul anilor, au fost propuse mai multe clasificări ale fenotipurilor de astm bronşic, pornind de la parametrii clinici şi fiziopatologici, factorii declanşatori, tipul inflamaţiei bronşice, caracteristicile temporale ale bolii etc. (1). 
Cea mai frecvent utilizată în practică este clasificarea astmului bronşic în funcție de prezența atopiei: fenotip atopic (alergic) şi non atopic.

Fenotipul cel mai frecvent întâlnit la copil este astmul atopic (alergic) fiind regăsit la peste $80 \%$ dintre pacienți. Acest fenotip este deseori asociat cu istoric familial de boli alergice, precum: dermatită atopică, rinită alergică, conjunctivită alergică, urticarie etc. (2).

Atopia reprezintă particularitatea genetic determinantă a unor indivizi de a dezvolta răspunsuri imune mediate de imunoglobulinele E (IgE) la alergeni comuni din mediu, asociate cu niveluri crescute de $\operatorname{IgE}$ serice, cu răspunsuri antigen-IgE specifice şi cu teste cutanate pozitive. Trebuie să menționăm că producția nivelelor bazale de IgE se află sub control genetic (8).

IgE sunt implicate în reacțiile de hipersensibilitate de tip I. Acestea se leagă de un receptor specific de pe mastocite şi bazofile. Expunerea unui individ la alergenul pentru care există sensibilizare va determina o sinteză crescută de $\operatorname{IgE}$ specifice care va declanşa o cascadă de reacții inflamatorii de tip alergic la nivelul mucoasei bronşice (3).

În anumite cazuri, prezența atopiei este însoțită de manifestări clinice specifice alergice (tuse, dispnee, wheezing, senzație de constricție toracică), precipitate de contactul cu alergenul pentru care există sensibilizare. Alteori, în absența manifestărilor clinice specifice de boală alergică, este necesară documentarea atopiei utilizând teste specifice (3).

Confirmarea sensibilizării alergice necesită investigații precum: testarea cutanată prick sau determinarea IgE specifice în ser. Se consideră că rezultatele testelor cutanate prick şi valorile IgE specifice serice se pot corela cu manifestările clinice. Prezența IgE specifice crescute în ser sau testul cutanat prick pozitiv indică faptul că individul a fost expus anterior la un alergen şi este sensibilizat, deci prezintă risc de a dezvolta manifestări clinice de tip alergic în momentul expunerii la alergenul la care este sensibilizat (7).

Fenotipul de astm bronşic atopic se însoţeşte în mod caracteristic de inflamație bronşică de tip eozinofilic. Copiii cu astm şi sensibilizare aeroalergenică prezintă frecvent o fracție crescută a oxidului nitric exhalat (FeNO) şi uneori eozinofilie (B-Eos) $(7,8)$.

Ambele reprezintă markeri de tip sistemic (BEos), respectiv de tip local, bronşic, (FeNO), ai inflamaţiei eozinofilice (6).

Un alt marker al inflamaţiei eozinofilice de tip sistemic este proteina cationică eozinofilică
(S-ECP), care poate fi determinată la copiii alergici cu $\operatorname{astm}(6)$.

Proteina cationică eozinofilică (ECP) este un marker specific activat şi eliberat de eozinofile. Aceasta mediază eliberarea histaminei din mastocite, mijlocind astfel hiperreactivitatea bronşică a căilor aeriene cu apariția bronhospasmului (4).

Oxidul nitric expirat (FeNO) este cel mai cunoscut marker noninvaziv al inflamaţiei de tip alergic în astm. Valoarea FeNO se corelează cu intensitatea inflamației eozinofilice la nivelul mucoasei bronşice. Dozarea de FeNO işi găseşte utilitatea în obiectivarea gradului de control al bolii. $\mathrm{Cu}$ toate acestea nu este utilizat de rutină în monitorizarea pacienților cu astm bronşic $(5,6)$.

\section{STUDIUL CLINIC}

Obiectivul studiului prospectiv realizat a fost stabilirea corelației dintre:

- nivelul seric al proteinei cationice eozinofilice (S-ECP) ca biomarker al procesului inflamator eozinofilic alergic şi prezența eozinofiliei;

- nivelul seric al proteinei cationice eozinofilice (S-ECP) ca biomarker al procesului inflamator eozinofilic alergic şi nivelul oxidului nitric exhalat la copiii cu astm alergic sensibilizaţi la aeroalergeni.

Toți pacienții au fost informați despre studiu, iar aparţinătorii acestora au semnat în prealabil Formularul de Consimţământ Informat avizat de Comisia de Etică.

\section{MATERIAL ŞI METODĂ}

Este un studiu prospectiv care a inclus un număr de 63 de copii cu vârsta cuprinsă între 5 şi 18 ani (având o vârstă medie de 14 ani), diagnosticați cu astm bronşic atopic sensibilizaţi la aeroalergeni. Pacienții au fost evaluați în Clinica de Pediatrie din Spitalul Clinic de Copii „Dr. Victor Gomoiu“, în perioada aprilie 2016-iulie 2017.

Criteriile de includere în studiu au fost:

1. vârsta cuprinsă între 5 şi 18 ani;

2. diagnostic de astm stabilit pe baza datelor anamnestico-clinice şi confirmat cu ajutorul spirometriei prin documentarea unei reversibilități a FEV1 după administrare salbutamol inhalator de cel puțin $12 \%$ şi/sau cel puțin $200 \mathrm{ml}$ față de valorile inițiale;

3. atopie cu sensibilizare la aeroalergeni dovedită prin evidențierea unor valori crescute ale $\operatorname{IgE}$ specifice din panelul respirator pediatric şi/sau tes- 
tare cutanată prick pozitivă față de cel puțin un aeroalergen (polenuri, acarieni, epitelii de animale, mucegaiuri, insecte).

Criteriile de excludere au fost:

1. pacienții cu astm nonatopic;

2. pacienții cu alte tipuri de sensibilizare (față de alergeni alimentari, medicamentoşi);

3. pacienți cu astm bronşic atopic care prezentau comorbidități asociate (boala de reflux gastroesofagian, rinite, sinuzite).

Testele cutanate prick au fost efectuate cu trusă standard europeană tip Stallergenes. S-au citit reacțiile cutanate apărute după 15 minute cu măsurarea diametrului papulei. S-au considerat ca fiind reacții pozitive când papula a avut un diametru $\geq 3 \mathrm{~mm}$ față de martorul negativ.

Valorile IgE specifice în ser au fost considerate pozitive daca au depăşit nivelul de $0,35 \mathrm{kU} / 1$.

În prima etapă a studiului, pentru fiecare pacient diagnosticat cu astm bronşic atopic şi sensibilizare aeroalergenică s-au determinat concomitent valoarea eozinofilelor şi nivelul seric al proteinei cationice eozinofilice (S-ECP).

Valoarea eozinofilelor sanguine a fost determinată cu ajutorul hemogramei (valoarea normală a eozinofilelor a fost considerată $<400$ celule $/ \mathrm{mmc}$ ).

Pentru măsurarea S-ECP s-a utilizat testul imunoenzimatic ELISA (enzyme-linked immunosor- bent assay). S-au considerat normale valorile situate $<13,3 \mu \mathrm{g} / 1$.

La fiecare pacient inclus în studiu s-a dozat FeNO utilizând dispozitivul NIOX MINO cu piesă bucală un analizor de chemoluminescență aprobat pentru dozarea de NO exhalat. Valorile normale ale FeNO au fost apreciate în functie de vârstă în conformitate cu ghidul britanic de management al astmului din 2014, astfel: $<20$ ppb la pacienţii cu vârstă $<12$ ani şi $<25$ ppb la pacienții cu vârstă $\geq$ 12 ani (7).

În final, a fost evaluată corelația dintre valoarea S-ECP şi prezența eozinofiliei, precum şi corelaţia dintre valoarea S-ECP şi nivelul FeNO.

\section{REZULTATE}

Din cei 63 de pacienți incluşi în lotul de studiu, 22 au avut valori normale ale S-ECP; dintre aceştia, 14 au avut un număr normal de eozinofile sanguine, iar 8 au prezentat eozinofilie. 41 dintre pacienții testați au prezentat valori crescute pentru S-ECP. Dintre aceştia, 13 au avut un număr normal de eozinofile sanguine, iar 28 au prezentat eozinofilie.

În Fig. 1 este consemnată corelația dintre nivelul proteinei cationice eozinofilice şi valoarea eozinofilelor sanguine.

\section{Corelația dintre valoarea S-ECP și prezența eozinofiliei}

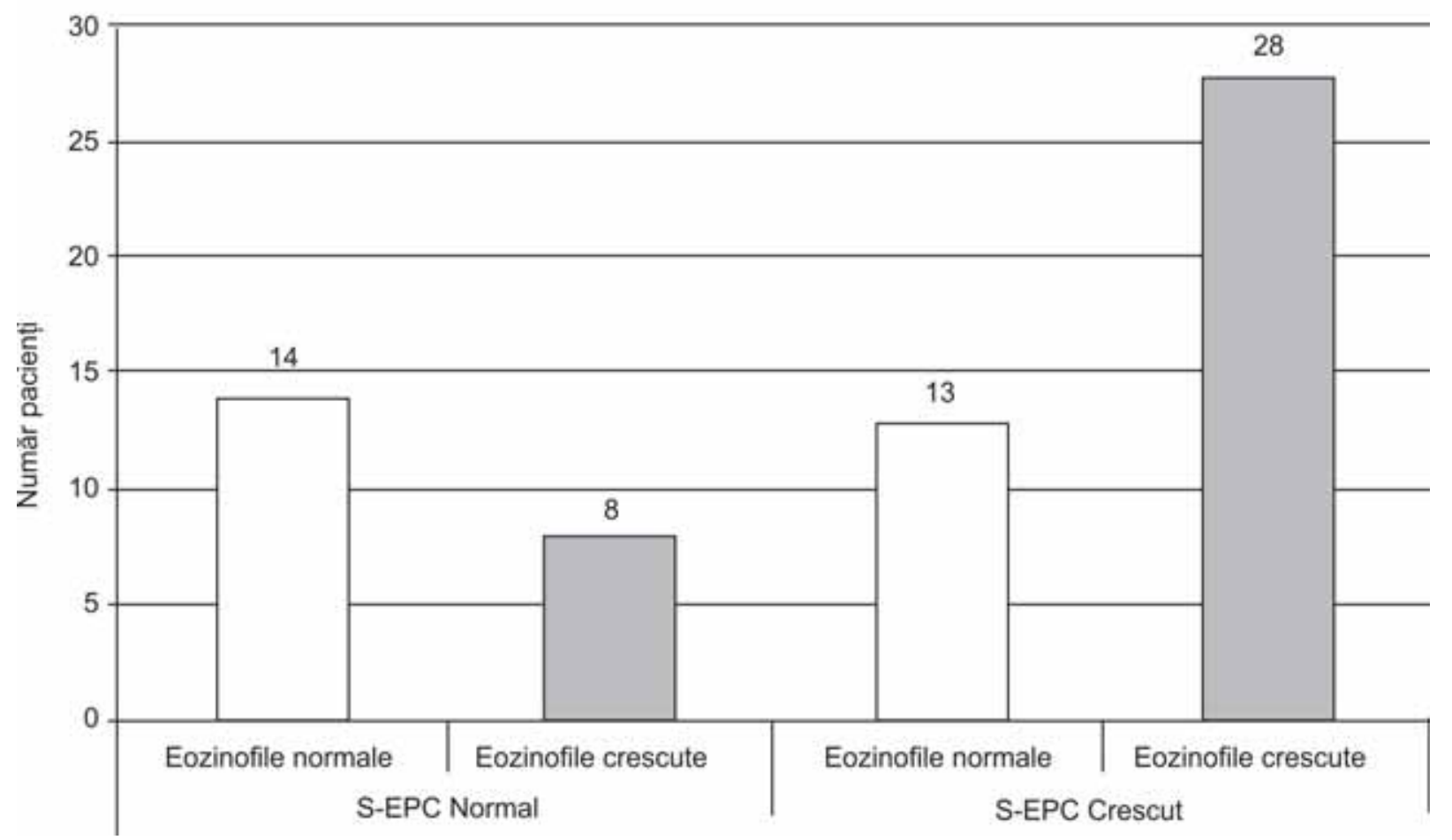

FIGURA 1. Reprezentarea grafică a valorii S-EPC şi eozinofile sangvine 
Aplicând funcția statistică Pearson Chi-Square Test pentru a evalua semnificația corelaţiei dintre valoarea crescută a S-ECP şi prezența eozinofilei, am obținut valoarea $\mathrm{p}=0,0146$ (semnificativă statistic).

15 dintre cei 22 pacienți cu valoare normală a S-ECP aveau concomitent o valoare normală a FeNO, în timp ce 7 pacienți prezentau valori crescute pentru FeNO, aspect reprezentat grafic în Fig. 2.

17 dintre cei 41 pacienți cu valoare crescută a S-ECP au avut valori normale ale FeNO, restul de 24 înregistrând valori crescute ale FeNO, aspect ilustrat în Fig. 2.

În Fig. 2 este consemnată corelația dintre nivelul proteinei cationice eozinofilice şi nivelul oxidului nitric.

Funcția statistică Pearson Chi-Square Test aplicată pentru a evalua corelația dintre valoarea SECP şi nivelul FeNO a furnizat valoarea $p=0,0432$ (semnificativă statistic).

\section{DISCUŢII}

Sensibilizarea specifică aeroalergenică este unul dintre cei mai importanți factori de risc în dezvoltarea simptomelor astmatice.
Exacerbările astmatice la triggeri alergenici apar la $60-90 \%$ dintre copii, iar la adult în proporție de $50 \%$.

Masurarea inflamației eozinofilice, rezultată din activarea răspunsului imun via limfocitele Th2, ajută la diagnosticarea, fenotiparea şi monitorizarea bolii pentru sesizarea deteriorării controlului astmatic, identificarea pacienților cu risc de exacerbare şi stabilirea atitudinii terapeutice (tratament corticosteroid/biologic).

În practica clinică, biomarkerii inflamației eozinofilice se măsoară cel mai adesea din sânge, aer exhalat şi urină. Alte metode de determinare a markerilor inflamației (cum ar cele prin analiza sputei, aspirat/lavaj bronhoalveolar cu ajutorul bronhoscopiei) presupun măsuri invazive sau greu accesibile care pot fi realizate doar în centre de cercetare ultraspecializate.

În ciuda varietății mari de markeri ai inflamației descrişi şi utilizaţi în studiile clinice de cercetare la adult, doar un număr mic s-au dovedit utili în monitorizarea astmului. Până în prezent, nu a fost identificat un biomarker optim pentru a măsura inflamaţia bronşică în astmul atopic.

În ultimii ani, au apărut mai multe publicații privind studiul biomarkerilor inflamației din astmul pediatric, însă cu rezultate controversate. Cercetările

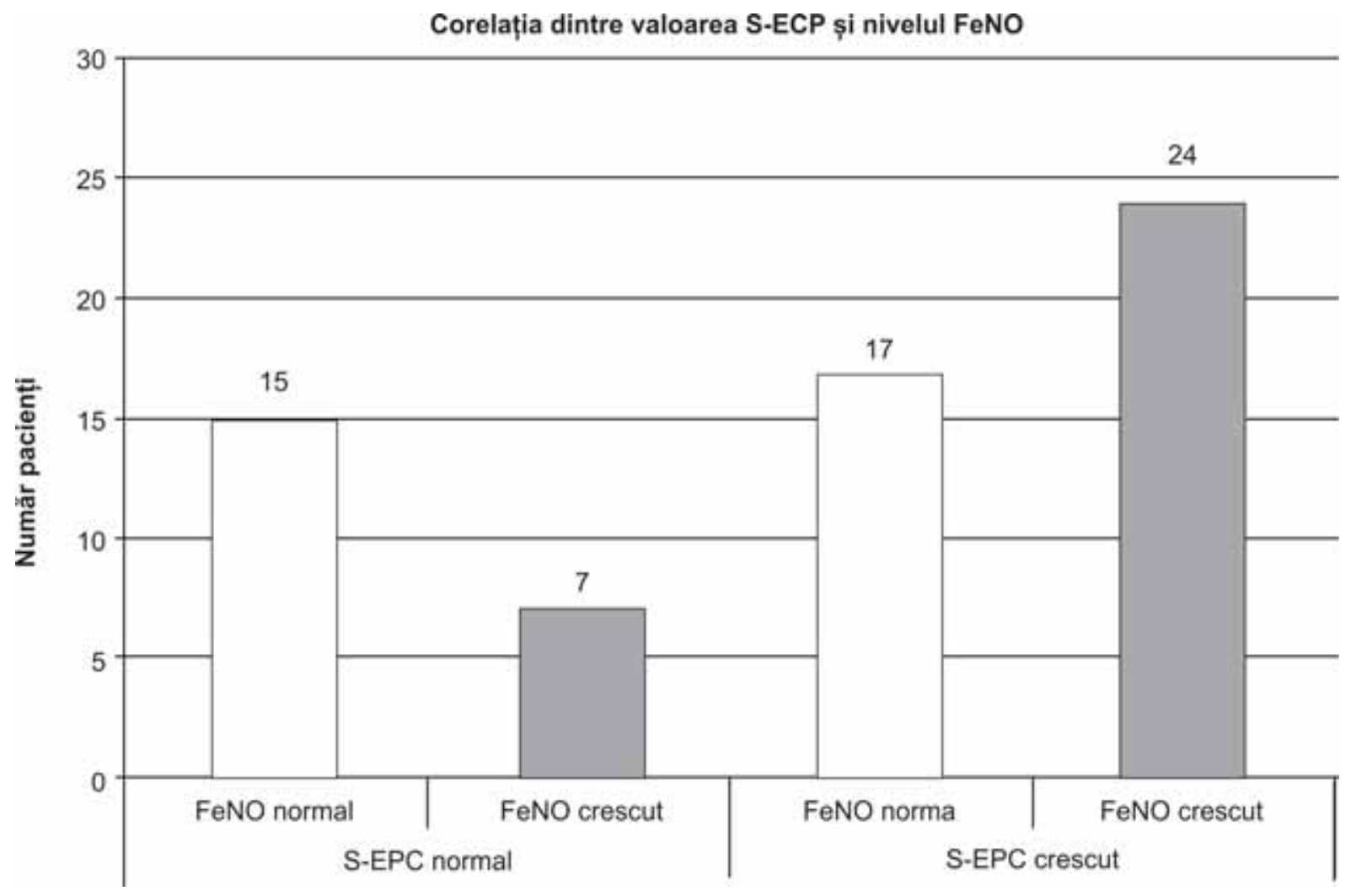

FIGURA 2. Reprezentarea grafică a valorii S-EPC şi nivelul FeNO 
actuale urmăresc să identifice un marker al fenotipurilor cu risc înalt de a dezvolta astm persistent sever la copii.

Uneori, măsurarea izolată a inflamației eozinofilice este insuficientă şi numai evaluarea combinată a acestor markeri, coroborate cu istoricul personal şi funcția pulmonară ajută la diagnosticarea, fenotiparea şi monitorizarea adecvată a astmului la copil.

\section{CONCLUZII}

Studiul de față a analizat dacă există o corelație între markerii inflamației eozinofilice determinați în sânge şi aerul exhalat, respectiv nivelul S-ECP, prezența eozinofiliei şi valoarea FeNO.
Rezultatele studiului prospectiv au relevat următoarele:

1. Nivelul S-ECP se corelează cu prezența eozinofiliei la copiii cu astm bronşic atopic sensibilizați la aeroalergeni.

2. Nivelul S-ECP se corelează cu valoarea FeNO la copiii cu astm bronşic atopic sensibilizaţi la aeroalergeni.

Testarea statusului inflamator prin aplicarea unor metode care să reflecte cît mai fidel procesul inflamator bronşic are implicaţii practice în monitorizarea adecvată a evoluției bolii sub tratamentul aplicat, precum şi în prevenirea acutizărilor astmatice. 